\title{
Opening Address of the Historical Section at the Meeting of the Institute at Edinburgh
}

\section{T. Hodgkin D.C.L., F.S.A}

To cite this article: T. Hodgkin D.C.L., F.S.A (1891) Opening Address of the Historical Section at the Meeting of the Institute at Edinburgh, Archaeological Journal, 48:1, 263-273, DOI: 10.1080/00665983.1891.10852480

To link to this article: http://dx.doi.org/10.1080/00665983.1891.10852480

$$
\text { 册 Published online: } 15 \text { Jul } 2014 .
$$

Submit your article to this journal $\sqsubset \pi$

Q View related articles $₫$ 
OPENING ADDRESS OF THE HISTORICAL SECTION AT THE MEETING OF THE INSTITUTE AT EDINBURGH. ${ }^{1}$

By T. HODGKIN, D.C.L., F.S.A

It has been a custom, frequently though not universally observed, for the President of the Historical Section, at a meeting of the Archæological Institute, to choose for the subject of his opening address the history of the city or town in which the meeting is held. To this custom we owe, besides many other excellent papers, some of the best chapters in Mr. Freeman's admirable book on "English Towns and Districts." I need hardly say that I do not propose to follow to-night the example set me by my illustrious predecessor. We, visitors from the southern side of the Border, come hither not to teach but to learn all that we may in the short space of this meeting concerning the history of the northern kingdom and especially concerning the history of its capital. It would be intolerable presumption for a visitor like myself, who has not made Scottish history a special subject of study, to retail a little second-hand information concerning this wonderful city, in the presence of men who have lived in it, and loved it from boyhood, who know every line of its history, and every verse of its ballad literature. The self-confident rhetorician who lectured on the Art of War in the presence of the mighty Hannibal, would be my fitting prototype if I addressed myself to any such presumptuous task.

Besides, I am sure that our Scottish neighbours will see that there would be something almost amounting to unkindness in asking a Northumbrian to recount the history of this fair jewel in the crown of Northumbria which

${ }^{1}$ Read at the Annual Meeting of the Institute, held at Edinburgh, August 12th, 1891. 
she so foolishly and so strangely lost. Can we Northumbrians forget that this city which is now for ever associated with your greatness and your glory was once ours; that it bears the name of our own national hero, Edwin, on its fore-front, that had it not been for the ravages of the Danes and the supineness of the kings of Wessex, we might have been at home in this city whose streets we now tread as strangers and foreigners? True, that you have made Edwin's Castle-what I fear we should never have done-one of the most beautiful capitals in Europe. True, that the happy mingling of Anglian and Celt has caused you to throw around it a glamour of poetry and romance to which, as a Northumbrian outpost, it would never have attained. Still the fact remains. This great possession once was ours and we foolishly or weakly threw it away. In the course of time we shall doubtless become reconciled to our loss, but the wound is still too recent (for a thousand years ago Edinburgh was still Northumbrian) to allow of our tracing without a sigh the fortunes of this Calilis of the North.

I will now, therefore, turn from this forbidden field and make a few remarks on a subject of general interest to us all, the relation of History to Archæology. (And here let me say once for all that I shall use Archæology in its widest sense, that sense in which this Institute uses it and which its etymology fully justifies, all that concerns the enquiry into things of ancient date). History and Archæology then have at once this element in common that they are solely occupied with the past, and in that past with the concern of the human race. While the Astronomer is investigating by instruments of wonderful and ever increasing delicacy the nature and the movements of bodies, some of which are at such an inconceivable distance that we should still be looking upon them though they had perished before the foundation of Rome: while the Social Philosopher is enquiring into the laws which govern the present relations of civilized man to his fellows and striving to deduce from those laws the character, whether individualist or socialistic, of the world of men that is to be ; while the Geologist, who like us looks into the past, is studying for the most part a past during which the world was manless, a past so 
distant as to be utterly beyond the range of all the instruments which we use, the attention of the Historian and Archæologist is concentrated on the past of the human race, and is directed to those among the vanished generations of mankind who can speak with some articulate voice to our own. For I think the mere discovery of a fossil man, to whatever geological period he might belong, would hardly be felt to be a fact coming within the proper domain of Archæology; while on the other hand every work of the human intellect, from the rude drawings of neolithic man in the caverns of Perigord to the death-warrant of Charles I., or the rough draft of the American Declaration of Independence, is of interest to the Archæologist.

This being so, how do we differentiate the two studies of History and Archæology? The difference between them is one not of subject but of method; it is a division of labour between the workers in the same field, not a division of territory between the owners of adjoining properties. Speaking generally (for the subject is notone which admits of an accurate scientific definition), I think we may say that the method of History is extensive, and that of Archæology intensive cultivation. We naturally expect the Historian to travel over a wide extent of time, and probably of space likewise, while we feel that we must allow the Archæologist to confine himself if he will to the events of a single month, the fortunes of a single family, or the registers of a single parish. Thus we may not improperly compare the instruments used by the Historian to the telescope, and those handled by the Archæologist to the microscope.

But there is another difference which we find generally existing between them, and which has to do with the nature of the materials used by each workman, and the degree to which he is dependent on others men's labours. The Historian-I am thinking of such men as Gibbon and Hume, Macaulay and Grote, Thierry and Sismondigenerally finds all his material in books, and can accomplish all his work without stirring beyond the pale of a well-stored library. The Archæologist on the other hand, has to gather his materials for himself out of a widely-varied and sometimes rough and difficult field. 
Now, it may be, he is opening the grave of a brachycephalic Celt or spelling out the lines of a grass-grown hut-circle. Then, he is cautiously questioning a peasant as to some half-forgotten piece of folk-lore or trying to recover a verse of an ancient ballad. Then, he is struggling with the contractions of a mouldy charter or trying to decipher the entries in a worm-eaten parish register. All this work calls for the exercise of boundless patience, and sumetimes it may be, he is tempted to grumble over the difficulties of his task and to think of his literary brother, with some of that envying discontent with which the discoverer, Stanley, in the earlier years of his African explorations, used to speak of the "easy-chair geographers," who, in the cushioned ease of Burlington Gardens, discussed the course of the rivers whose banks his weary feet had trodden and the extent of the forest from which he had hardly emerged with life.

Yet the Historian also if he works conscientiously, does not find that his path lies always through pleasant places. True his materials generally exist within the two covers of a book, but what books some of them are. Ponderous folios, often written in detestable Latin and sometimes without an Index, page after page of which he must turn over on the mere chance of finding a fact or an allusion which may help or hinder a theory. German monographs full of learning but void of arrangement in which he must plough through half a page to find the predicate of a sentence, and then through half a chapter to find the author's thought, remaining perhaps uncertain even at the end what is the proposition which the writer upholds and what is that which he combats. Memoirs written years after the events recorded, by men or women of inaccurate minds, papers too precious to be cast aside as rubbish and yet continually tormenting him by statements obviously inconsistent with fact. Worst of all perhaps, the works of other compilers who have evidently bestowed time and labour on his subject, yet who indicate so casually the sources from which they derive their materials, that he is never sure whether he is safe or not in repeating the story as they have told it. Such are many of the materials with which the Historian has to deal and which make his work, 
even if he be in the centre of a superb library of reference, like the Bodleian or the British Museum, not always a pleasant pastime. And if he be not close to such a library; if he be working in some remote district of the country with no other library but his own and the circulating library within fifty miles of him, he will surely find that he does not possess the very book which contains the one quotation that is indispensable to clear up the difficulty which faces him.

Of course the two kinds of labour which I have been describing, shade off into one another by imperceptible d degrees. As a rule the Historian does not himself collate manuscripts nor study registers. He generally expects, and with reason, that this work will be done for him by others. But especially when he is dealing with compara$\ddot{\infty}$ tively modern times, a historian like Gardiner or Ranke ๘ will have so much to do in consulting State papers which Thave not been printed or, letters which have not yet been calendared, that practically he has to do the work of an Archæologist as well as his own. And almost every Archæologist who has chosen a really worthy subject of study, will find himself some time or other, taking up the pen of a historian in order to shew by a few broad and simple touches how his subject is connected with the main course of a nation's history.

But in the main the distinction which I have here drawn will be admitted to be true. The Archæologist collects facts relating to the past, and the Historian

arranges them. The Archæologist hopes at least that he I shall discover some fact previously unknown or forgotten. . 'The Historian hardly hopes to do more than combine facts previously known in such a manner as to present them forcibly to the minds of his readers. The Archæologist's work partakes most of the nature of a Science, the Historian's of an Art.

And here I will allow myself a short digression in order to remark that for one great portion of history which is of fascinating interest to some of us, the Historian has practically to thank the Archæologist for almost the whole of his materials. I allude to that long and mysterious interval in the story of our country which is covered by the words biitannia romana. For almost 400 years FoI, XIVIII 
-for a time all but as long as that which separates us from the discovery of America, the Roman Legionary was amongst us. Yet how little the mere book-historians tell us of his doings. A few, a very few pages in the Histories and the Agricola of Tacitus; some random notices in the Historia Augusta; and some precious sentences in Ammianus Marcellinus : there is, I think, all that the Historians properly so-called have told concerning a dependency the conquest of which one would have thought might have fascinated their imaginations and occupied their pens almost as much as the deeds of Clive and Hastings in India have attracted and employed British Historians. But so it was not, and it is really to the patient labours of our antiguaries, of the Camdens, Stukeleys and Horsleys of past generations, of the RoachSmiths and Stuarts and Bruces of our own day, that we owe nearly all the knowledge which we do possess of those four centuries which must have exercised so vast an influence on the British land, and through that land on the Anglian people.

Will that knowledge hereafter be greatly increased? It is my earnest hope and expectation that it will. As yet we are in a state of tantalising ignorance on many points. We really know hardly anything of the relations-assuredly not always warlike relations-of the Roman invaders to the people of the land. The mere fact of the existence of say, 4000 or 5000 soldiers with their camp followers between the Firths of Clyde and Forth, of a similar but much larger body of men between Tyne and Solway, must have enormously quickened trade in those regions and yet how little we know of the course of trade between the Briton and the Roman? Again we know from the Notitia that one camp was inhabited by Asturians from Spain, another by Tungrians from Belgium, another by Batavians, another by Frisians and so forth. But what we do not know is how the nationality of these auxiliary garrisons was maintained. Were there fresh drafts of Asturians, Tungrians, Batavians every five or ten years to replace the waste of time and war? Or did the "sons of the legion," the offspring of intermarriage with the Brigantian or Caledonian women around them step into the places of their 
fathers? And if so, with this ever-increasing tide of British blood and ever dwindling element of foreign nationality, how were the Alae and Cohortes guarded from the dangerous tendency to fraternise with the natives around them, once their enemies, now their brothers-inlaw and their cousins?

These are only two specimens of the questions concerning the Roman occupation of Britain which still await their answer from Archæology.

But let me return to my main subject.

The two classes of literary labourers whom I have endeavoured to describe, generally work harmoniously together and excellent is the result of such co-ordinated toil. Sometimes however, as I have already hinted, there is a certain amount of heart-burning and strife between them, to which the temptation is all the stronger, because their fields of labour lie so close together. For still, as in classical Greece, and in the days of English and Scottish Borderers, it is neighbours who are apt to quarrel. The mathematician's or physiologist's criticisms on our pursuits leave us quite unwounded, but we are sensitive to the rebuke of those who, like ourselves, are striving to recover the form and fashion of buried centuries.

The Historian growing weary of the endless pigeonholes of small facts, collected with labour, but apparently leading to no result and illustrating no great principle, which the Archæologist exhibits to him with pride, perhaps loses his temper and calls him "a man of parochial mind, a drudge, a collector of useless tritles." It was in some such mood as this that Carlyle stormed at the Prussian book-makers who had been at work before him on the history of his hero, Friedrich II.

"Alas, the books are not cosmic, they are chaotic ; and turn out unexpectedly void of instruction to us. Small use in a talent of writing, if there be not first of all the talent of discerning, of loyally recognising : of discriminating what is to be written! Books born mostly of Chaos-which want all things even an Index-are a painful object. In sorrow and disgust you wander over those multitudinous books; you dwell in endless regiou. : of the superficial, of the nugatory; to your bewildered 
sense it is as if no insight into the real heart of Friedrich and his affairs were anywhere to be had. Truth is, the Prussian Dryasdust, otherwise an honest fellow and not afraid of labour, excels all other Dryasdusts yet known. I have often sorrowfully felt as if there were not in Nature, for darkness, dreariness, immethodic platitude, anything comparable to him. He writes big books wanting in almost every quality, and does not even give an Index to them. $\mathrm{He}$ has made of Friedrich's History a wide-spread inorganic trackless matter, dismal to your mind and barren as a continent of Brandenburg sand! Enough, he could do no other; I have striven to forgive him. Let the reader now forgive me and think sometimes what probably my raw material was."

So much for the Historian out of temper, railing at the A rchæologist. I cannot quote any similar tirade of an Archæologist against the Historian, but I know, I can see clearly, what is the word which is often trembling on his lips and which only politeness restrains him from uttering-" superficial." And truly it must be hard for a man who has devoted the best years of his life to the illustration of some minute point in English history, say the custom of Gavelkind or the boundaries of Wessex and Mercia, to come across another man who has achieved some reputation as a writer of English history, and who has little more than an Oxford Passman's knowledge on either subject.

Well, as is so often the case in this kind of controversy, there is reason in both complaints, but in both also "potior est conditio defendentis." The Archæologist does sometimes need to be reminded, in the midst of his laborious collection of facts, that it is not every kind of fact in relation to the past, which is worth collecting. Can any one imagine that the Archæologist of 2391 will care to know, except in the broadest and most general way, what were the times of arrival and departure of the trains at the Waverley station in 1891? Or will it serve any useful purpose even fifty years hence to ascertain the auth ${ }^{2}$ s and describe the plots of one-tenth part of the novels wnich to-day live their little life on the shelves of our circulating libraries, and then "perish for ever and no man regardeth them." No ; the facts which the Archæo- 
logist gathers with such praiseworthy patience and industry must be facts which are worth collecting, facts which have some bearing, however remote, on the great historic interests of our country or our race. And I think it is not inconsistent with the spirit of the Inductive Philosophy to say that the most fructus will be obtained from these facts which are gathered in consequence of the existence of some theory in the collector's mind which the facts will either prove or disprove. Only he must hold his theory, especially in the earlier stages of his enquiry, with sufficient lightness, ready to abandon or to modify it as soon as ever he sees. that the facts fairly interpreted are making against it, and never daring to say " even in the faintest underbreath, "Si les taits ne sont pas mpour moi, tant pis pour les faits."

I may perhaps without presumption venture to name two men who seem to me to be admirable examples of scientific collectors of Archæological facts. One is Sir Arthur Mitchell, the well-known author of "The Past in I the Present," who from the rude implements and ruder dwellings still existing among the inhabitants of the Hebrides, developed a whole theory of the co-existence of different strata of civilisation, a theory which has at least modified the sharp lines of demarcation which previous enquirers had drawn between the Stone, the Bronze, and the Iron ages. The other is Mr. F. Seebohm, whom the University of Edinburgh has recently honoured with her degree. In the case of the last gentleman, who is a personal friend of my own, I have watched with peculiar interest and admiration, the gradual collection of facts If relating to the land-system of our Teutonic ancestors, beginning with the observation of the shape of the fields, and the distribution of the allotments in a rural parish in Hertfordshire, and working back from these through the centuries, till the enquirer finds himself face to face with the Germania of Tacitus, or watching the Coloni tilling the lands round a Roman villa.

But the Historian also has something to say for himself when charged by his Archæological brother with writing on subjects with which he has only a superficial acquaintance. His chief plea is drawn from the shortness of human life. After all there are but twenty-four hours in 
the day, and for most of us not more than threescore years at most of effectual literary labour. "I have a long journey before me," the Historian may fairly argue, "and if I stop to pick up and to polish every stone on my road that may possibly prove to be an agate, I shall never reach my journey's end."

This often recurring controversy between the minute and ithe broad style of treatment of historical facts has been sometimes recalled to my mind, when I have been travelling in Cornwall or Devonshire and have gazed upon the hedges which there border the road on either side. Such magnificent earthworks they are, often ten or twelve feet high, and when seen in spring so rich in all kinds of organic life, wild flowers in splendid profusion, ivy, ferns, and moss in endless variety, swarms of insects, and here and there the nest of some bird which the ordinary Englishman has never seen out of a museum. The thought occurs to one-and it is a true reflection- "a lifetime would not be too long for him who would really study a hundred yards of this hedge-row." And y et when the artist comes this way, even though the hedge-row should come in the foreground of his picture a few hours work will enable him to depict it with sufficient exactness to make every beholder exclaim "that is a Cornish hedge-row," and if it come into the middle distance a few hasty washes of colour will be all that he dare bestow upon it.

The close attention and life-long study represent the conscientious labour which the Archæologist bestows on the records, or the dialect, or the antiquities of a single parish. In the interests of science I think we must class him above his brother the literary artist who gathers the history of many counties, perhaps of many centuries into a. single picture. But yet there is room also for the Historian, though it may be that with the increasing definiteness of our knowledge and the higher standard of accuracy which is required he may have to take a somewhat lower position than of old in the presence of his brethren. His broad washes of colour have their use as well as the microscopic studies of the Archæologist. Without the wide panoramic picture which the historian presents to us, our knowledge of the past would consist of a multitude of detached fragments which we could 
not co-ordinate one with the other. Especially perhaps is he needed in this day when our science, in common with most other sciences, is in danger of suffering from over-specialisation. If some care be not taken against this danger we may find ourselves before long divided into an an upper and lower intellectual class, the upper class consisting of some thousand or more groups of scientific enquirers each of which is intelligible to itself but to no one in the world beside, while the lower class finding that all the conversation of men of science is hopelessly over its head, renounces in despair the attempt to assimilate any of their thoughts and contents itself with the "Shilling Shocker," and "the Illustrated Police News."

From such isolation of thought, it is the business of the Historian to preserve the great mass of his countrymen, and therefore I venture to think there will still, in the future, be room for him as well as for his more aspiring brother, the original Archæologist. 